\title{
アルカリ塩化物融解塩におけるフルオロ錯体と ヨード錯体
}

北村孝雄*, 一瀬光之尉**, 小島 次 雄**

\section{Formation of Fluoride and Iodide Complexes in Fused Alkali Chloride Solvents}

\author{
Takao KITAMURA*, Mitsunojo ICHISE** and \\ Tsugio KoJIMA**
}

\begin{abstract}
Complex formation of zinc (II), copper (I), nickel (II), cobalt (II), iron (II), cadmium (II), lead (II), and thallium ( I ), with fluoride ion in $\mathrm{NaCl}-\mathrm{CsCl}$ (equimol.), and of nickel (II), copper (I), and zinc (II) with iodide ion in $\mathrm{LiCl}-\mathrm{NaCl}\left(\mathrm{LiCl}\right.$ : $80 \mathrm{~mol} \%$ ) was studied at about $600^{\circ} \mathrm{C}$ by emf measurements and potential sweep voltammetry. Stability constants of fluoride complexes of nickel (II), cobalt (II), iron (II), and zinc (II), and of iodide complexes of nickel (II), copper (I), and zinc (II) were determined.

The tendency toward complex formation in the fused chloride solvents was compared with that in fused $\mathrm{LiCl}-\mathrm{KCl}$ (eut.), and the difference was discussed in terms of solvent cation effect. An experimental value for the solvent cation effect was obtained for the iodide complexes of copper (I), and it agreed with the value calculated from the theoretical electromotive forces of the single halide salts.
\end{abstract}

\section{1 緒 言 (Introduction)}

融解塩中で種々の溶質金属イオンが錯体を形成する傾 向は溶媒により異なるため，水溶液系における錯体形成 に基づく Schwarzenbach の考察がそのままの形ではあ

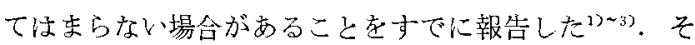
の原因として融解塩中の錯体形成反忘は，溶質金属イオ ンに配位している溶媒陰イオンが添加陰イカンと交換す る反応であるため, 添加陰イオンだけでなく, 溶媒陰イ オンの影響老受けること，および金属イオンに配位した 陰イオンが交換する際に同時汇溶媒陽イオンのまわりの 陰イオンも置き変わるため, 溶媒陽イオンの影響をも受 けることが考えられた。

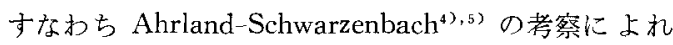

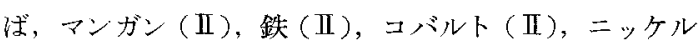

* 四国工業技術試験所 (高松市花の宫町2-3-3)Government Industrial Research Institute, Shikoku(Hananomiya, Takamatsu)

** 京都大学工学部 (京都市左京区.吉田本町) Faculty of Engineering, Kyoto University (Yoshida, Sakyo-ku, Kyoto)
（II），覀鉛(II)，などC 型金属イオン法塩化リチウム塩 化カリウム (共晶) 融解塩系において, 添加フッ化物イ オンとフルオロ錯体を形成することが予想されるにもか かわらず，前報の結果によればろ，これらの金属イオン はフルオロ錯体を形成しない。これ溶媒にかなりのリ チウムイオンが含まれているため, 添加したフッ化物イ ホンがリチウムイオンとのイオン対として存在し，その 結果フッ化物イオンの活量が低下すること纪よると推定 された・したがってリチウムイオンを含まない溶媒とし て塩化ナトリウム塩化セシウム融解塩を用いれば，フ ッ化物イオンの活量が比較的高いため, フルオロ錯体の 生成が期待される.

またB型金属イオンである銀（Ｉ），銅（Ｉ），カドミウ ム（II）などの塩化リチウム一塩化カリウム(共晶) 融解 塩系におけるヨード錯体は，水溶液系あるい滛融解硝酸 塩系に比べ生成エネルギーが小さい1110)。これはおもに 塩化物イオンが B 型金属イオンに強く配位するためと考 えられる、しかし, 溶媒陽イオンを選ぶことによってヨ ウ化物イオンの活動度が、上がれば，塩化物融解塩系にお いても，より安定なヨード錯体の生成が期待される.す 
なわち塩化りチウム-塩化カリウム融解塩系では添加し たヨウ化物イオンが㤬とえどカリウムイオンとのイオン 対の形で存在すると考えられる ${ }^{6)}$ ため，ヨウ化物イオン の活動度が比較的低いが, 溶媒として塩化リチウム塩化 ナトリウム融解塩を用いれば，ヨウ化物イオンはおるに ナトリウムイオンとのイオン対で存在すると考えられる ため，ヨウ化物イオンの活動度が高く，したがってヨー ド錯体形成にとって有利であると考えられる。

本報告では，塩化ナトリウム一塩化セシウム（等モル） 融解塩中で, 二三のフルオ口錯体の安定度定数と, さら に塩化りチウムー塩化ナトリウム（塩化リチウム 80 モル \%) 融解塩中で, 二三のヨード錯体の安定度定数索, 起 電力測定法あるい恃電位揥引ボルタンメトリーによって 測定する，その結果から塩化物融解㸃系での錯体形成の 自由エネルギーを算出し，錯体形成に及ぼす溶媒の効果 を，点電荷のクーロンエネルギー捛よび，単味金属八ラ イドの標準単極電位から概算したエネルギーにより比較 考察する。

\section{2 実験 (Experimental)}

\section{1 溶媒亡試料}

塩化りチウム一塩化ナトリウム融解塩壮精製した塩化 リチウム ${ }^{92} 20.8 \mathrm{~g}$ と試薬特級の塩化ナトリウム $11.2 \mathrm{~g}$ を，また塩化ナトりウム一塩化セシウム融解塩の場合は 塩化リチウム $12.4 \mathrm{~g}$ と試薬特級の塩化セシウム $35.6 \mathrm{~g}$ を，また塩化りチウムー塩化カリウム融解塩の場合は塩 化りチウム $14.9 \mathrm{~g}$ と塩化カリウム $18.6 \mathrm{~g}$ をそれぞれ外径 $3.5 \mathrm{~cm}$ 深さ $10 \mathrm{~cm}$ のパレックスビーカーに秤取 する.これを炉内のセルに納め，七 ル内を塩化水素ガスで置換した後昇 温した。融解後塩化水素を 30 分間吹 き込み，次にセル内をアルゴン置換 し，さらに約 40 分間アルゴンを吹き 込んで調製した。

錯形成剂は試薬特級のフッ化ナト リウムを白金ルツボ内で融解した後 これをぺレット状に固化し調製，あ るい注試薬特級のヨウ化ナトリウム を真空乾燥して調製した。その他の 試料の調製は前報”と同じである。

\section{2 電極その他}

照合電極注第一種の銀電極（塩化 銀湢度 $0.1 \mathrm{~mol} / \mathrm{kg}$ (塩化ナトリウ ム-塩化セシウム系)，扔よび 0.5 $\mathrm{mol} / \mathrm{kg}$ (塩化リチウムー塩化ナトリ ウム系)）用い，液絡はピンホー
ルによった．液絡抵抗は $1 \sim 1.5 \mathrm{k} \Omega$ で内部液面は測定 の間ほぼ变化がなかった，他の電極類は前報2々同じで あった.

測定はアルゴンふん团気中 $600^{\circ} \mathrm{C}$ で行なった。溶質金 属イオン濃度は塩化ナトリウムー塩化セシウム系では, $0.005 \mathrm{~mol} / \mathrm{kg}$, 塩化リチウム-塩化ナトリウム系で法 0.01 $\mathrm{mol} / \mathrm{kg}$ であった． 添加陰イオン濃度はフッ化ナトリウ 么の場合，0.1 1 mol $/ \mathrm{kg}, \exists$ ウ化ナトリウムの場合 0.2 $\sim 2 \mathrm{~mol} / \mathrm{kg}$ の範囲にわたった.

3 結果と考察 (Results and Discussion)

\section{1 フルオ口錯体}

塩化ナトリウムー塩化セシウム融解塩系での鉄 (II)， コバルト (II), ニッケル(II), 銅 ( I )の $\mathrm{M}^{+} / \mathrm{M}$ 電極電 位は 60 分閒以上 $\pm 1 \mathrm{mV}$ 以内で安定であった. また覀鉛 (II)，カドミウム(II)，鉛(II)，タリウム(I)の場合ボ ルタンメトリーを用いたが析出ピーク電位は60分間以上 $\pm 2 \mathrm{mV}$ 以内で安定だった，各溶質金属イオンをフッ化 ナトリウムで滴定した結果を Fig. 1 に示す.ファ化ナ トリウム濃度の増大とともに電位が早に移動した場合に ついて，平均配位数 $p$ の錯体を仮定し安定度定数 $\beta_{p}$ 在 求め,さらに Leden のグラフ解析法 ${ }^{11}$ 適用して遂次 安定度定数を求めた。結果を Table 1 に示す.

Table 1 の結果から塩化ナトリウム塩化セシウム融 解媓系では, Schwarzenbachの分類によるC型金属イオ ンのマンガン(II)，コバルト(II)，鉄(II)，㧍上び亜鈆

Table 1 Stability constants of complexes in chloride solvents

\begin{tabular}{c|l|c|c|c|c|c}
\hline \multicolumn{1}{c|}{$\mathrm{M}-\mathrm{L}$} & \multicolumn{1}{c|}{ solvent } & $\log \hat{\beta}_{p}$ & $p$ & $\beta_{1}$ & $\beta_{2}$ & temp. ${ }^{\circ} \mathrm{C}$ \\
\hline $\mathrm{Zn}^{2+}-\mathrm{F}^{-}$ & $\mathrm{NaCl}-\mathrm{CsCl}$ & 0.19 & 0.9 & 1.6 & - & 595 \\
$\mathrm{Zn}^{2+}-\mathrm{F}^{-}$ & $\mathrm{LiCl}-\mathrm{KCl}$ & -- & - & - & - & 599 \\
$\mathrm{Ni}^{2+}-\mathrm{F}^{-}$ & $\mathrm{NaCl}-\mathrm{CsCl}$ & 0.73 & 1.5 & 1.8 & 3.9 & 603 \\
$\mathrm{Ni}^{2+}-\mathrm{F}^{-}$ & $\mathrm{LiCl}-\mathrm{KCl}$ & - & - & - & - & 595 \\
$\mathrm{Co}^{2+}-\mathrm{F}^{-}$ & $\mathrm{NaCl}-\mathrm{CsCl}$ & 0.33 & 1.1 & 1.7 & 0.5 & 605 \\
$\mathrm{Co}^{2+}-\mathrm{F}^{-}$ & $\mathrm{LiCl}-\mathrm{KCl}$ & - & - & - & - & 602 \\
$\mathrm{Fe}^{2+}-\mathrm{F}^{-}$ & $\mathrm{NaCl}-\mathrm{CsCl}$ & 1.1 & 1.4 & 4.3 & 10 & 598 \\
$\mathrm{Fe}^{2+}-\mathrm{F}^{-}$ & $\mathrm{LiCl}-\mathrm{KCl}$ & - & - & - & - & 595 \\
$\mathrm{Tl}^{+}-\mathrm{F}^{-}$ & both in & & & & & \\
$\mathrm{Pb}^{2+}-\mathrm{F}^{-}$ & $\mathrm{NaCl}-\mathrm{CsCl}$ & - & - & - & - & $\mathrm{ca.} 600$ \\
$\mathrm{Cd}^{2+}-\mathrm{F}^{-}$ & and LiCl-KCl & & & & & \\
$\mathrm{Cu}^{+}-\mathrm{F}^{-}$ & & & & & & \\
$\mathrm{Cu}^{+}-\mathrm{I}^{-}$ & $\mathrm{LiCl}-\mathrm{NaCl}$ & 0.05 & 1.2 & 0.85 & 0.25 & 597 \\
$\mathrm{Cu}^{+}-\mathrm{I}^{-}$ & $\mathrm{LiCl}-\mathrm{KCl}$ & -0.11 & 1.1 & 0.65 & 0.12 & 600 \\
$\mathrm{Ni}^{2+}-\mathrm{I}^{-}$ & $\mathrm{LiCl}-\mathrm{NaCl}$ & -0.63 & 1.5 & 0.12 & 0.1 & 600 \\
$\mathrm{Ni}^{2+}-\mathrm{I}^{-}$ & $\mathrm{LiCl}-\mathrm{KCl}$ & - & - & - & - & 450 \\
$\mathrm{Zn}^{2+}-\mathrm{I}^{-}$ & $\mathrm{LiCl}-\mathrm{NaCl}$ & -0.06 & 0.79 & 1.1 & - & 597 \\
$\mathrm{Zn}^{2+}-\mathrm{I}^{-}$ & $\mathrm{LiCl}-\mathrm{KCl}$ & - & - & - & - & 450 \\
\hline & & & & & &
\end{tabular}




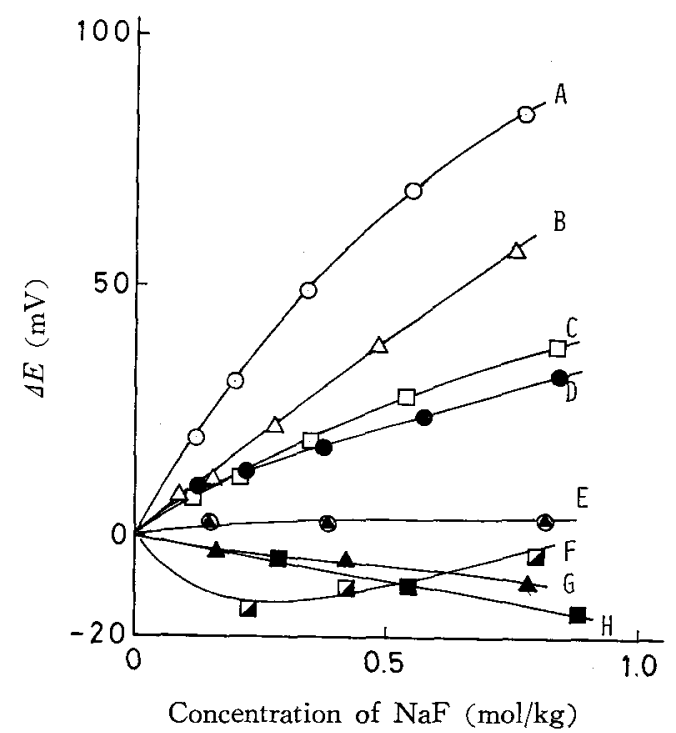

Fig. 1 Titration curves of metal ions in $\mathrm{NaCl}-\mathrm{CsCl}$
$\mathrm{A}: \mathrm{Fe}^{2+}, \mathrm{B}: \mathrm{Ni}^{2++}, \mathrm{C}: \mathrm{Co}^{2+}, \mathrm{D}: \mathrm{Zn}^{2+}$
$\mathrm{E}: \mathrm{Tl}^{+}, \mathrm{F}: \mathrm{Pb}^{2+}, \mathrm{G}: \mathrm{Cd}^{2+}, \mathrm{H}: \mathrm{Cu}^{+}$

（II）はフルオ口錯体を形成し，B型金属イオンである 銅(I), タリウム(I), 鉛(II)，カドミウム (II) はフ ルオ口錯体を形成しない.これらの挙動は Fig. 3 の Ahrland の分類に従っていることがわかる.

一方塩化リチウム一塩化カリウム (共晶) 融解壏中の これら金属イオンはフルオロ錯体を形成しないことが確 かめられており，したがって Fig. 3 の区画線による予 想に従わない：この上うに両融解塩系におけるフルオ口 錯体形成の傾向は顕著に異なることが認められる．その 理由としてまず金属イオンの溶存状態が両溶媒系で異な ることが考えられる.観察の結果では塩化リチウムー塩 化カリウム融解塩中のニッケル(II)は青紫色であるが， 塩化ナトリウム一塩化セシウム融解塩中のニッケル (II) は青色である.これはニッケル（II）の電子吸収スペク トルを種々の溶媒系で研究した結果と定性的には一致す ると推定され, 前者は八面体配位のニッケルに近く, 後 者は四面体配位に近いと推定される.しかし，両系でこ のようにニッケル（II）の溶存状態が違うのはニッケル （II）に配位した塩化物イオンの外側にある溶媒陽イオン の分極性等の違以によるものであり?，錯体形成に二次 的な影響を与える因子と考えられる.

融解揾中の錯体形成は最近傍イオンの交換だけを考虑 すると，次式で表わされる。

$$
\mathrm{MX}+\mathrm{SL} \rightleftharpoons \mathrm{ML}+\mathrm{SX}
$$

ここでM溶質金属イオン，S 江溶媒陽イオン，X $\mathrm{X}$ 溶媒陰イオン，そしてLは添加陰イオンを表わす，上記 反応のエネルギーは点電掎クーロンエネルギー ${ }^{12}$ )るるい
は単塩の単極電位 ${ }^{23}$ を用いて概算できる. Table 2 には 実験值と両法による理論值を示した.

単塩の単極電位による理論值は定量的には不十分だが 定性的には実験結果をほ活正しく予想している。一方ク 一ロンカによるエネルギー $\Delta U$ 注 Pauling イオン半径 を用い次式により算出した。

$$
\begin{aligned}
\Delta \mathrm{U}= & -\mathrm{Ne}^{2}\left\{z_{\mathrm{M}} z_{\mathrm{L}} /\left(r_{\mathrm{M}}+r_{\mathrm{L}}\right)+z_{\mathrm{S}} z_{\mathbf{X}} /\left(r_{\mathrm{S}}+r_{\mathrm{X}}\right)\right. \\
& \left.-z_{\mathrm{M}} z_{\mathbf{X}} /\left(r_{\mathrm{M}}+r_{\mathbf{X}}\right)-z_{\mathrm{S}} z_{\mathrm{L}} /\left(r_{\mathrm{S}}+r_{\mathrm{L}}\right)\right\}
\end{aligned}
$$

$e$ 弾位電荷, $N$ はアボガドロ数, $z_{\mathrm{i}}$ は各イオンの電 荷, $r$ はイオン半径を表わす。溶媒陽イオンの半径はナ トリウムとせシウムのモル比加重平均犆を用いた。しか し，(2) 式による值は実験結果との一致が悪く，二価金 属イオンの錯体形成の傾向をまったく予想することがで きない。

両䒺で錯体形成の傾向が異なる原因は，(1) 式中に現 われた一次的な因子だけを考えれば，溶媒陽イオンと陰 イオンのイオン対が両系で異なることにあると考えられ る.この溶媒陽イオン効果は次式上り理論的に算出でき $\succsim^{2)}$.

$$
\begin{aligned}
& F_{\mathrm{d}}=\Delta F^{\circ}{ }_{\mathrm{NaCl}-\mathrm{CsC} 1}-\Delta F_{\mathrm{LiCl}-\mathrm{KCl}}^{\circ}=-(F / Z) \\
& \left(E_{\mathrm{Na}, \mathrm{Cs}, \mathrm{Cl}}^{\circ}-E^{\circ}{ }_{\mathrm{Na}, \mathrm{Cs}, \mathrm{F}}+E_{\mathrm{Li}, \mathrm{K}, \mathrm{F}}^{\circ}-E_{\mathrm{Li}, \mathrm{K}, \mathrm{Cl}}^{\circ}\right)
\end{aligned}
$$

溶媒陽イオンの平均配位数 $Z=4$ と仮定し, Hamer に よる単塩の単極電位を用いれば $F_{\mathrm{d}}=1.8 \mathrm{kcal}$ となり, 塩化ナトリウム一塩化セシウム系のフルオロ錯体がより 安定であることになる．実験では塩化りチウム塩化力 リウム系に执いてフルオ口錯体が形成されないため，溶 媒効果の実験值は決好られな、しかし，塩化ナトリウ ムー塩化セシウム系でフルオロ錯体が形成されることは 上記の計算結果が実験結果と定性的に一致することを示 している。

\section{$3.2 \exists ー ト ゙$ 錯体}

塩化リチウムー塩化ナトリウム融解塩中の銅 (I), 二 ックル (II)の電極電位㧍よび隶鈆( II)の固体微小電極上 への析出ピーク電位はそれぞれ60分問以上 $\pm 1 \mathrm{mV}$ お び $\pm 2 \mathrm{mV}$ 以内で安定であった.

これらの金属イオンをヨウ化ナトリウムで滴定した結 果を Fig. 2 に示す. ヨウ化ナトリウム濃度の增大とと もに電極電位あるいはピーク電位が卑に移動し, 錯体形 成を示した、滴定の間，銅(I)，亜鉛(II)溶液怡無色透 明であるが，ニッケル(II)溶液はヨウ化ナトリウム添加 前の青紫色から添加後は赤味を帯び, 終に湆赤紫色に なった，後者はヨウ化カリウムーヨウ化セシウム融解塩 系のニッケル(I)の色，あるいは他の溶媒におけるニッ ケル(II)のヨード錯体の色 ${ }^{8)}$ とほぼ一致し, 本系でのヨ 一ド錯体生成を裹付けている.

またニッケル(II)，亜鉛(II)が本系でヨード錯体を形 成ししたことは，塩化りチウム塩化カリウム（共晶)融 解塩系でヨード錯体を形成しなかったことと対比される 


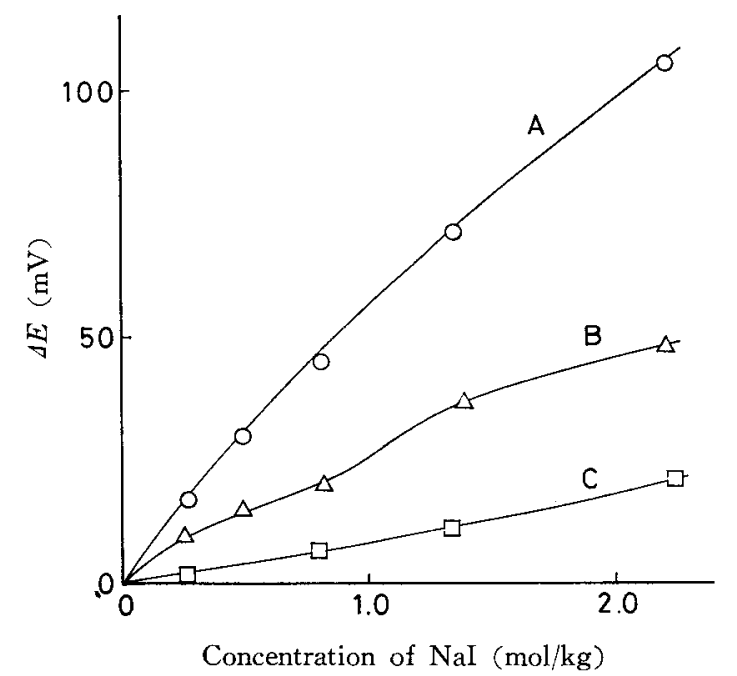

Fig. 2 Titration curves of metal ion in LiCl$\mathrm{NaCl}$

$$
\mathrm{A}: \mathrm{Cu}^{+}, \mathrm{B}: \mathrm{Zn}^{2+}, \mathrm{C}: \mathrm{Ni}^{2+}
$$

Table 2 Free energy of complex formation

\begin{tabular}{c|c|r|r|r}
\hline \hline $\mathrm{M}^{+}-\mathrm{L}^{-}$ & Solvent & \multicolumn{1}{|c|}{$\begin{array}{c}\Delta F^{\circ} \text { obs. } \\
\mathrm{kcal} / \mathrm{mol}\end{array}$} & $\begin{array}{c}\Delta F^{\circ} \text { cal } \\
\mathrm{kcal} / \mathrm{mol}\end{array}$ & $\begin{array}{c}\Delta U^{\circ} \mathrm{cal} \\
\mathrm{kcal} / \mathrm{mol}\end{array}$ \\
\hline $\mathrm{Zn}^{2+}-\mathrm{F}^{-}$ & $\mathrm{NaCl}-\mathrm{CsCl}$ & 4.6 & 0.3 & 35.6 \\
$\mathrm{Zn}^{2+}-\mathrm{F}^{-}$ & $\mathrm{LiCl}-\mathrm{KCl}$ & - & - & 28.9 \\
$\mathrm{Ni}^{2+}-\mathrm{F}^{-}$ & $\mathrm{NaCl}-\mathrm{CsCl}$ & 5.7 & 1.3 & 39.1 \\
$\mathrm{Ni}^{2+}-\mathrm{F}^{-}$ & $\mathrm{LiCl}-\mathrm{KCl}$ & - & - & 32.4 \\
$\mathrm{Co}^{2+}-\mathrm{F}^{-}$ & $\mathrm{NaCl}-\mathrm{CsCl}$ & 5.0 & 1.1 & 37.0 \\
$\mathrm{Co}^{2+}-\mathrm{F}^{-}$ & $\mathrm{LiCl}-\mathrm{KCl}$ & - & - & 30.3 \\
$\mathrm{Fe}^{2+}-\mathrm{F}^{-}$ & $\mathrm{NaCl}-\mathrm{CsCl}$ & 6.9 & 1.3 & 34.7 \\
$\mathrm{Fe}^{2+}-\mathrm{F}^{-}$ & $\mathrm{LiCl}-\mathrm{KCl}$ & - & - & 28.0 \\
$\mathrm{Cu}^{+}-\mathrm{F}^{-}$ & $\mathrm{NaCl}-\mathrm{CsCl}$ & - & - & 4.9 \\
$\mathrm{Cu}^{+}-\mathrm{F}^{-}$ & $\mathrm{LiCl}-\mathrm{KCl}$ & - & - & - \\
$\mathrm{Cu}^{+}-\mathrm{I}^{-}$ & $\mathrm{LiCl}-\mathrm{NaCl}$ & 5.5 & 2.3 & 2.4 \\
$\mathrm{Cu}^{+}-\mathrm{I}^{-}$ & $\mathrm{LiCl}-\mathrm{KCl}$ & 4.6 & 1.4 & 0.7 \\
$\mathrm{Ni}^{2+} \mathrm{I}^{-}$ & $\mathrm{LiCl}-\mathrm{NaCl}$ & 3.6 & 0.4 & - \\
$\mathrm{Ni}^{2+} \mathrm{I}^{-}$ & $\mathrm{LiCl}-\mathrm{KCl}$ & - & - & - \\
$\mathrm{Zn}^{2+}-\mathrm{I}^{-}$ & $\mathrm{LiCl}-\mathrm{NaCl}$ & 5.0 & 1.1 & - \\
$\mathrm{Zn}^{2+}-\mathrm{I}^{-}$ & $\mathrm{LiCl}-\mathrm{KCl}$ & - & - & - \\
\hline
\end{tabular}

$F^{\circ}$ obs. : at about $600^{\circ} \mathrm{C}$, except for $\mathrm{Ni}^{2+}-\mathrm{I}^{-}$, and $\mathrm{Zn}^{2+} \mathrm{I}^{-}$in $\mathrm{LiCl}-\mathrm{KCl}\left(450^{\circ} \mathrm{C}\right)$

$F^{\circ}$ cal. : at $600^{\circ} \mathrm{C}$

結果であり，塩化リチウムー塩化ナトリウム系ではヨー ド錯体形成が促進される結果，ニッケル(II)，と亜鉛 （II）が Fig. 3 の区画線に上る予想と異なった挙動を 示すことが認められた。

安定度定数と配位数を Table 1 亿, 錯体形成のエネ ルギーの理論值と実験值を Table 2 に示す. ヨード錯 体の場合も前記のフルオロ錯体と同様, 単極電位から算

\begin{tabular}{|c|c|c|c|c|c|c|}
\hline $\mathrm{Cr} \mathrm{Mn}$ & $\mathrm{Fe} \mathrm{Co}$ & $\mathrm{Ni}$ & $\mathrm{Cu} \mathrm{Zn}$ & & $\mathrm{Ge}$ & \\
\hline Mo Tc & Ru Rh & $\mathrm{Pd}$ & $\mathrm{AgCd}$ & In & $\mathrm{Sr}$ & St \\
\hline $\operatorname{Re}$ & Os Ir & $\mathrm{Pt}$ & Au $\mathrm{Hg}$ & $\mathrm{TI}$ & & $\mathrm{Bi}$ \\
\hline
\end{tabular}

Fig. 3 Classification of metals by Ahrland Iodide ion coordinates more stable than fluoride ion for metal ions inside the pyramid, and vice versa

出した值は定性的に実験結果と同じ傾向を示すが、クー ロンエネルギーによる值は二価イオンの場合実験結果と 異なった傾向を示す.

次にヨード錯体形成に対する溶媒の効果を評価するた めに，塩化リチウムー塩化カリウム（共晶）融解塩中 600 ${ }^{\circ} \mathrm{C}$ でョウ化カリウムによる銅 (I) の滴定を行なった. 結果は Table 1 に示した. 銅 (I)のヨード錯体は塩化 リチウムー塩化カリウム融解塩中より，塩化リチウムー塩 化ナトリウム融解塩中の方が安定であり，両系での錯形 成の自由エネルギーの差は $0.9 \mathrm{kcal} / \mathrm{mol}$ となる. 理論 值は Hamerによる単塩の単極電位から計算すると $F_{\mathrm{d}}=$ $0.9 \mathrm{kcal}$, 点電荷モデルでは (2) 式㙐系に適用し 1.7 $\mathrm{kcal}$ を得る。したがって塩化リチウムー塩化ナトリウム 系のヨード錯体が溶媒陽イオン効果のため安定なことに なり, 銅 (I) のヨート錯体については実験結果と良好 な一致を示す.

なお，兩算出法による溶媒効果の理論值の差は錯形成 エネルギーの理論値の差に比べ，かなり小さい，したが って, 溶媒効果算出の際には，(1) 式の MX, ML に対 するエネルギーが消去されることを考虑すると, 点電荷 モデルにより錯形成の傾问の予測ができないのは，二価 金属イオンの配位エネルギーを単純な点電荷モデルによ っては適切に評価できないためであることを示唆してい る.

\section{4 結 論 (Conclusion)}

（1）塩化リチウム塩化カリウム（共晶）融解塩中と 異なり，塩化ナトリウム一塩化セシウム融解塩中では， 二価遷移金属イオンがフルオ口錯体を形成する.

(2) 塩化りチウムー塩化ナトリウム融解塩中の銅 (I) 江塩化リチウム一塩化カリウム (共晶) 融解塩中より安 定なヨード錯体を形成する、また塩化りチウム一塩化力 リウム融解塩中と異なり, 塩化リチウム一塩化ナトリウ ム融解塩中では监鉛 (II)，ニッケル（II）がョード錯体 を形成寸る。

（3）したがって，塩化物融解塩中において溶媒陽イオ ンを変えれば，錯体形成の傾向を変えることができる が，この溶媒陽イオンの効果は，単塩の単極電位を用い 
て, 定性的记予測できた。

$<1527>$ (ReceivedJuly 21,1975)

\section{文献}

1）北村孝婎，一瀬光之尉，小岛次雄，本誌 39，700 (1971).

2) 北村孝雄, 一瀨光之尉, 小島次蜼, ibid. 43, 119(1975).

3）北村孝雄，一瀬光之尉，小島次雄，ibid. 43, 703(1975).

4) S. Ahrland, E. Larsson, Acta Chem. Scand. 8,354 (1958).

5) G. Schwarzenbach, Experimentia. Suppl. 5, 162 (1956).
6) Y. Marcus, Israel J. Chem. 10, 659 (1972).

7) J. Brynestad, C.R. Boston, G.P. Smith, J. Chem. Phys. 47, 3179 (1967)

8) Naida S. Gill, R.S. Nyholm, J. Chem. Soc. 1959, (3997).

9）西 朋太, 一瀬光之尉，本誌 32，155 (1964).

10) S.H. White, D. Inman, B. Jones, Trans. Faraday Soc. 64, 2841 (1968).

11) I. Leden, Z. Phys. Chem. 188, 160 (1941).

12) J. Braunstein, J.D. Brill, J. Phys. Chem. 70, 1261 (1966).

\section{第 10 回半真体・集積回路シンポジゥ台 \\ 要気化学協会電子材料委貝会主催 \\ 応用物理学会, 精機学会, 電気学会東京支部, 虫子通信学会

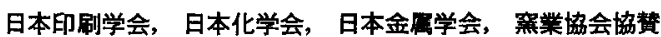

半導体技術，集皘回路技術はますます技術革新の速度を早めています。特沉れらの製造に当っては，各種の技術

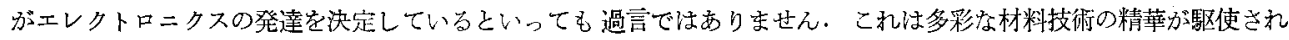
ているわけで，令の技術的意義を討論し，明日の材料技術や生産技術のあり方を見出すため，毎年春秋 2 回のシンポ

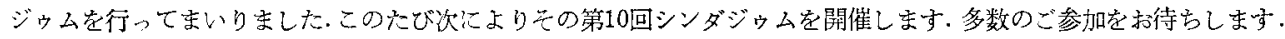

第 1 日 20 日（木） $10: 00 \sim 16: 00$

1. FAMOS 型 $p$-ROM の記憶消失機構について 三菱電機中研, 北伊丹 中尾皖治, “蔵満洋一 張間寛一, 中山春夫, 松本平分

2. III-V 䒺化合物半導体表面酸化膜の化学租成

$$
\text { ソニー中研 井上 誠 }
$$

3. $\mathrm{H}_{3} \mathrm{PO}_{4}-\mathrm{H}_{2} \mathrm{O}_{2}-\mathrm{H}_{2} \mathrm{O}$ 系による $\mathrm{GaAs}$ エェ

$$
\text { チングの Kinetics ソニー中研 森 芳文 }
$$

4. ガラスパッシベーション

一PhO 系ガラスの電気泳動法—

三菱電機北伊丹, 生研 ${ }^{\circ}$ 渡壁弥一郎, 梶原康也

蒲生 浩, 大野克弘, 藤林㢣次, 西楽隆司

5.トリクロルエチレン酸化によるシリコン中

の積層欠陥の制御 ソニー半導体 服部 毅

6. T型ショットキゲート GaAsFET

武藏野通研 “浅井和義, 菅田孝之, 井田雅夫 藤本正友

7. 梂スパッタイングによるアルミ蒸着

日本電気, 九州日本電気 。樋口孝一 加納一边, 久保田武应, 高畑幸一郎

招待講演 I. スパッ夕装置の最近の傾间

$$
\text { 日電バリアン 細川值吉 }
$$

第 2 日・ 21 日(金) $10: 00 \sim 16: 10$

8. 高濃度 ${ }^{81} \mathrm{P}^{+}$イオン注入したシリコンの結晶性に 対する熱処理勃果

日本電気集積回路 ○宇田啓一郎, 鸭志田元孝

9. 二層金風膜のアンダーカットに関する電気化学的 検討

日立製作所日立研 ${ }^{\circ}$ 華阔雅信, 浅井 治
10. ISI 微細構造の観察

三菱電機中研 ${ }^{\circ}$ 加藤忠雄, 松川隆行, 小山 浩 河律 哲, 小宮敬義

11. UM ハードプレート

$$
\text { 一フォトマスク用新感光材料一 }
$$

富士写真フィルム中研 住藤正倫, 藤井逸夫 招待講演 II. 半導体 · 集積回路の加工, ウエハー 技術の動向

兼松セミコンダタター 未木胎啺（予定）

招待韝演 III. 電子ビームリソグラフィーの技術の

動向 日立製作所中研 右高正俊

招待講演 IV. X 線リソグラフィーの技術の動向 武藏野通研 中心了（予定）

(参加子約申迄締切 5 月15日（土）

氏名，勤務先，連絡先を明記のう充費用を添えて (現金書留) 期間内にお束し込み下さい。な期限

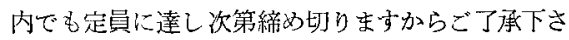
W.

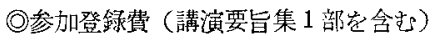

予的 会員 5,000円 会員外 6,000円 学生会員 3,000 円

予約外 会員 5,500円 会負外 6,500円 学生会員 3,500円

()講演要旨集 1 部 3,000 円（送料共）

部数に制限が方りますから予約願います。

○講演, 参加登録, 要旨集申込先

巴100 東京都千代田区有楽町 1-12-1 新有楽町ビ 儿 電気化学協会電子材料委員会 (03-214-6001, 6002). 